\title{
Perbedaan Komponen Vegetatif dan Generatif Pada Lima Aksesi Padi Hitam (Oryza sativa L.) di Kecamatan Indihiang Tasikmalaya Jawa Barat
}

\author{
Author(s): Siti Nurhidayah*(1); Dona Setia Umbara ${ }^{(1)}$ \\ (1) Program Studi Agroteknologi Pertanian, Universitas Perjuangan Tasikmalaya \\ * Corresponding author: nurhidayah.unper@gmail.com
}

\begin{abstract}
ABSTRAK
Padi hitam merupakan pangan fungsional yang baik dikonsumsi bagi penderita penyakit degeneratif karena kandungan antosianin dan antioksidannya yang tinggi. Penelitian ini bertujuan untuk mengevaluasi keragaan karakter agronomi pada 5 aksesi (PH3, PH4, PH5, PH7, dan PH8) padi hitam asal Tasikmalaya. Penelitian menggunakan rancangan kelompok lengkap teracak satu faktor yaitu aksesi padi hitam. Data dianalisis menggunakan analisis ragam dan uji lanjut Duncan taraf 5\%. Hasil menunjukkan bahwa aksesi berpengaruh nyata terhadap tinggi tanaman, umur berbunga, umur panen, panjang malai, panjang daun bendera, jumlah gabah isi, dan jumlah gabah hampa. Aksesi PH5 (asal Indihiang) memiliki keragaan terbaik dari aksesi lainnya yaitu memiliki panjang daun bendera $29.9 \mathrm{~cm}$, umur panen 104 hari setelah tanam dan jumlah gabah total 215 butir per malai dibandingkan dengan varietas Inpari 32 dan Situbagendit.
\end{abstract}

\section{Kata Kunci: \\ Antosianin; \\ Antioksidan; \\ Degenerative; \\ Padi hitam;}

\begin{abstract}
Keywords: $\quad$ Black rice is a functional food that is good for people with degenerative diseases because of its high anthocyanin and antioxidants content. This study aims to evaluate of agronomy characters of the 5 accession of black rice from exploration. The study used a Antioxidants; $\quad$ complete randomized block design of one factor, namely black rice accession. Data were Black rice. analyzed using variance analysis and Duncan's test $\alpha$ 5\%. The results showed that Black rice; accession significantly affected plant height, flowering stage age, harvest stage age, Degenerative; $\quad$ panicle length, flag leaf length, number of filled seeds, and a total number of seeds. Indihiang genotype the best agronomic performance compared to other accessions and checked varieties. The flag leaf length, harvest stage age, and a total number of seeds of accession $G 7$ were $29.9 \mathrm{~cm}, 104$ days, and 215 grains respectively.
\end{abstract}




\section{PENDAHULUAN}

Padi hitam (black rice) merupakan salah satu jenis padi yang tumbuh tersebar di benua Asia termasuk negara Indonesia (Kushwaha, 2016). Padi beras hitam di Indonesia pada saat ini sudah mulai susah untuk diperoleh bahkan sudah hampir punah karena para petani sudah tidak menanam padi hitam. Hal tersebut disebabkan padi beras hitam umumnya mempunyai umur tanaman yang panjang, habitus tanaman yang tinggi, dan produktivitas rendah yang menjadi kendala dalam usaha budidayanya (Kristamtini, Sutarno, Wiranti, \& Widyayanti, 2016).

Beras hitam yang banyak dibudidayakan oleh petani pada umumnya merupakan varietas lokal, dengan tingkat keberadaan yang telah mengalami penurunan menjadi kurang dari 20\% Suardi and Ridwan (2009) karena tersingkirkan oleh padi varietas unggul (Anhar, 2013). Keberadaan Padi lokal (Oryza sativa L.) memiliki tingkat keragaman genetik yang tinggi berdasarkan karakter warna beras diantaranya beras putih, merah putih, coklat-merah, kuning, hitam dan ungu (Utami, Ilhami, \& Hanarida, 2010). Ketersediaan sumber daya genetik berupa plasma nutfah merupakan faktor yang sangat penting untuk perbaikan genetik tanaman (Surahman, Santosa, \& Nisya, 2009). Padi lokal merupakan salah satu sumber keragaman genetik tahan dan toleran terhadap cakaman biotik dan abiotik serta kualitas yang sangat disukai oleh masyarakat Indonesia umumnya (Sitaresmi et al., 2013;Rohaeni dan Hastini, 2015).

Beras hitam memiliki pigmen baik Suardi and Ridwan (2009), dengan kandungan senyawa phenol dan kadar antosianin lebih tinggi daripada beras lainnya Walter et al. (2013); Maulida dan Guntarti (2015); Huang and Lai (2016), sehingga baik dikonsumsi untuk kesehatan (Warman, Sobrizal, Suliansyah, Swasti, \&
Syarif, 2016). Beras hitam memiliki khasiat sebagai antioksidan, mencegah gangguan fungsi ginjal, memperbaiki kerusakan sel hati, mencegah kanker, mencegah anemia Suardi and Ridwan (2009), mencegah penuaan dini Suhery et al., (2016) serta cocok untuk makanan diet penderita diabetes melitus (Hartati, 2013). Berdasarkan berbagai laporan, kadar phenol dari beras hitam sebanyak 7.14 mg/g bahan Moongngarm et al., (2012) dan $9.4 \mathrm{mg} \mathrm{GAE} / \mathrm{g}$ Walter et al., (2013), sedangkan kadar antosianin sebanyak 6-16 $\%$ Maulida and Guntarti (2015) yaitu dengan kandungan pada bagian luar 6-11 $\mathrm{mg} / \mathrm{g}$ bahan dan bagian dalam 3-6 mg/g bahan (Huang \& Lai, 2016). Umumnya padi beras hitam memiliki indeks glikemik rendah dengan kadar amilosa tinggi (Indrasari, 2009).

Sampai saat ini pemerintah masih belum mengeluarkan varietas unggul padi beras hitam. Menurut laporan Suardi and Ridwan (2009) diperoleh galur harapan hasil persilangan dengan kriteria beras hitam berumur genjah (90-100 hari), tinggi tanaman (90-100 cm) dengan penampilan mirip tetuanya Silugonggo. Tujuan penelitian ini untuk mengevaluasi beberapa komponen vegetatif dan generatif dari 5 aksesi padi hitam.

\section{METODOLOGI \\ Waktu dan Tempat}

Penelitian dilaksanakan pada bulan Maret - Agustus 2018 di sawah petani Kecamatan Indihiang, Kota Tasikmalaya, Jawa Barat. Perhitungan komponen hasil dilaksanakan di laboratorium Ilmu Pengetahuan Alam Dasar Universitas Perjuangan Tasikmalaya.

\section{Bahan dan Alat}

Bahan yang digunakan meliputi benih padi beras hitam sebanyak 5 aksesi (PH3, PH4, PH5, PH7 dan PH8), serta varietas pembanding Situ Bagendit dan Inpari 32 (Tabel 1). Aksesi tersebut berasal 
dari beberapa petani kota dan Kabupaten Tasikmalaya serta Dinas Kota dan Dinas Kabupaten Tasikmalaya. Pemupukan menggunakan pupuk NPK phonska dosis $200 \mathrm{~kg} /$ ha yang diaplikasikan satu kali pada saat penanaman dan pupuk Urea $100 \mathrm{~kg} / \mathrm{ha}$ yang diaplikasikan pada 1 MST, 3 MST dan 5 MST. Alat yang digunakan meliputi peralatan budidaya pada umumnya, ember, ajir, meteran, dan kamera.

Tabel 1. Aksesi padi beras hitam hasil eksplorasi di Tasikmalaya

\begin{tabular}{cll}
\hline No. & Aksesi & \multicolumn{1}{c}{ Asal } \\
\hline 1 & PH3 & Dinas Kabupaten Tasikmalaya \\
2 & PH8 & Petani Kecamatan Singaparna \\
3 & PH7 & Petani Kecamatan Rajapolah \\
4 & PH4 & Dinas Kota Tasikmalaya \\
5 & PH5 & Petani Kecamatan Indihiang \\
6 & Situ Bagendit & - \\
7 & Inpari 32 & - \\
\hline
\end{tabular}

Keterangan: $\mathrm{PH}=$ padi hitam

\section{Metode Penelitian}

Rancangan yang digunakan adalah rancangan kelompok lengkap teracak satu faktor yaitu aksesi. Setiap aksesi dan varietas pembanding ditanam pada petakan kecil dengan ulangan sebanyak 3 kali. Setiap aksesi ditanam 2 bibit per lubang dengan jarak tanam $25 \mathrm{~cm} \times 25 \mathrm{~cm}$ sehingga total sebanyak 21 unit percobaan.

Pengamatan yang diukur terdiri atas pengamatan karakter vegetatif dan karakter generatif dari 5 tanaman contoh. Karakter yang diukur meliputi: tinggi tanaman $(\mathrm{cm})$, jumlah anakan total, jumlah anakan produktif, panjang malai $(\mathrm{cm})$, bobot 1,000 butir (g), jumlah gabah bernas per malai, jumlah gabah total per malai, umur berbunga (hari), dan umur panen (hari). Data dianalisis menggunakan uji $\mathrm{F}$ dan uji lanjut berganda Duncan 5\%.

\section{HASIL DAN PEMBAHASAN Analisis Ragam Padi Beras Hitam dan Padi Beras Putih}

Berdasarkan hasil analisis ragam menunjukkan bahwa genotipe yang diuji berpengaruh sangat nyata terhadap karakter tinggi tanaman dan umur berbunga. Genotipe yang diuji juga berpengaruh nyata terhadap karakter panjang daun bendera, umur berbunga, umur panen, panjang malai, jumlah gabah isi, dan jumlah gabah total, serta tidak berpengaruh nyata terhadap karakter jumlah anakan produktif dan jumlah anakan total dan bobot seribu butir (Tabel 2).

Tabel 2. Rekapitulasi Analisis Ragam Karakter Agronomi Aksesi Padi

\begin{tabular}{|c|c|c|}
\hline Karakter & Rata-rata & KK \\
\hline UB (hr) & $69,86^{* *}$ & 2,41 \\
\hline $\mathrm{TT}(\mathrm{cm})$ & $124,15^{* *}$ & 2,65 \\
\hline$\Sigma \mathrm{AT}$ & $16,86 \mathrm{tn}$ & 13,00 \\
\hline$\Sigma$ AP & $16,67 \mathrm{tn}$ & 13,34 \\
\hline $\mathrm{UP}(\mathrm{hr})$ & $102,79^{*}$ & 1,98 \\
\hline PM (cm) & 22,92 * & 5,83 \\
\hline $\operatorname{PDB}(\mathrm{cm})$ & $28,03^{*}$ & 8,69 \\
\hline JGI & $161,41^{*}$ & 13,16 \\
\hline JGT & $179,21^{* *}$ & 11,38 \\
\hline BSB (g) & $27,95 \mathrm{tn}$ & 7,99 \\
\hline
\end{tabular}

Keterangan: TT (tinggi tanaman), $\Sigma$ AT (jumlah anakan total) $\Sigma$ AP (jumlah anakan produktif), UB (umur berbunga), PDB (panjang daun bendera), UP (umur panen), PM (panjang malai), JGI (jumlah gabah isi), JGT (jumlah gabah total (JGT), BSB (bobot seribu butir), ${ }^{*}$ (nyata), ${ }^{* *}$ (sangat nyata), tn (tidak nyata), KK (koefisien keragaman)

Koefisien keragaman hasil analisis berkisar 2,41 - 13,34\%. Hal tersebut 
menunjukkan bahwa rancangan yang dipakai dalam penelitian menunjukkan tingkat ketepatan dan keandalan yang baik (Gomez \& Gomez, 1984). Berdasarkan rekapitulasi analisis ragam, rata - rata umur berbunga $69.86 \mathrm{HST}$, tinggi tanaman $124.15 \mathrm{~cm}$, jumlah anakan total 17 anakan, umur panen $103 \mathrm{HST}$, panjang malai 22.92 $\mathrm{cm}$, panjang daun bendera $28.03 \mathrm{~cm}$, jumlah gabah isi sebanyak 161 butir, jumlah gabah total 179 butir dan bobot seribu butir $27.95 \mathrm{~g}$.

\begin{abstract}
Keragaan Karakter Vegetatif
Berdasarkan Tabel 3, hasil menunjukkan bahwa tanaman padi hitam memiliki kisaran tinggi $129-137 \mathrm{~cm}$ sedangkan varietas pembanding Inpari 32 dan Situbagendit sekitar $103-104 \mathrm{~cm}$. Berdasarkan laporan Kristamtini et al., (2016) tinggi tanaman padi beras hitam Cempo Ireng dan padi beras hitam tidak berbulu memiliki tinggi tanaman sekitar $174-180 \mathrm{~cm}$. Sedangkan Situbagendit sekitar $110-120 \mathrm{~cm}$.
\end{abstract}

Tabel 3. Keragaan Karakter Vegetatif Padi Hitam di Kecamatan Indihiang

\begin{tabular}{cllcc}
\hline Aksesi & TT $(\mathbf{c m})$ & PDB $(\mathbf{c m})$ & $\boldsymbol{\Sigma} \mathbf{A T}$ & $\boldsymbol{\Sigma} \mathbf{A P}$ \\
\hline PH3 & $130 \mathrm{~b}$ & $28.3 \mathrm{ab}$ & 15 & 15 \\
PH8 & $133 \mathrm{ab}$ & $30.0 \mathrm{a}$ & 17 & 17 \\
PH7 & $129 \mathrm{~b}$ & $27.9 \mathrm{abc}$ & 16 & 16 \\
PH4 & $137 \mathrm{a}$ & $29.8 \mathrm{a}$ & 19 & 18 \\
PH5 & $133 \mathrm{ab}$ & $29.9 \mathrm{a}$ & 16 & 16 \\
Inpari32 & $104 \mathrm{c}$ & $24.5 \mathrm{c}$ & 18 & 18 \\
Situbagendit & $103 \mathrm{c}$ & $25.9 \mathrm{bc}$ & 18 & 18 \\
\hline
\end{tabular}

Keterangan : TT (tinggi tanaman), $\Sigma$ AT (jumlah anakan total) $\Sigma$ AP (jumlah anakan produktif), PDB (panjang daun bendera), huruf yang sama pada kolom yang sama menunjukkan tidak berbeda nyata berdasarkan uji lanjut Duncan 5\%

Panjang daun bendera berkisar 27.9 $30 \mathrm{~cm}$ sedangkan varietas pembanding 24.5 - $25.9 \mathrm{~cm}$. Panjang daun bendera semua aksesi yang diuji tidak berbeda nyata. Panjang daun bendera PH4, PH5, dan PH8 memiliki daun bendera lebih panjang daripada varietas pembanding. Sementara panjang daun bendera aksesi PH3 tidak berbeda nyata dengan varietas Situbagendit dan aksesi PH7 tidak berbeda nyata dengan varietas pembanding Inpari 32 dan Situbagendit.

Karakter jumlah anakan produktif dan jumlah anakan total padi hitam sekitar 15 - 19 anakan sementara varietas pembanding sebanyak 18 anakan. Jumlah anakan produktif dan jumlah anakan total aksesi yang diuji tidak berbeda nyata dengan varietas pembanding Inpari 32 dan Situbagendit.

\begin{abstract}
Keragaan Karakter Generatif
Berdasarkan hasil analisis menunjukkan bahwa seluruh aksesi yang diuji menampakan keragaan yang berbeda terhadap karakter yang diamati kecuali karakter bobot seribu butir. Karakter umur berbunga padi hitam berada pada kisaran $67-74$ HST sedangkan varietas pembanding 67- 74 HST. Sebanyak 3 aksesi (PH3, PH5, dan PH8) memiliki umur berbunga tidak berbeda nyata dengan varietas Inpari 32. Sebanyak 1 aksesi (PH7) memiliki umur berbunga lebih dalam dari seluruh akesi padi hitam dan varietas pembanding yang diuji dengan umur berbunga 74HST. Aksesi PH4 memiliki umur berbunga lebih genjah (67HST) daripada varietas Inpari32 (70HST) dan tidak berbeda nyata dengan varietas pembanding Situbagendit (67HST).
\end{abstract}


Umur panen padi hitam berkisar 103 - 105 HST dan padi putih sebagai varietas pembanding memiliki umur panen 101 HST. Padi hitam aksesi PH4 dan PH8 tidak berbeda dengan varietas Inpari 32 dan Situbagendit yaitu memiliki umur sekitar 103 HST. Sementara aksesi PH3 (105 HST), PH5 (104 HST), dan PH7 (104 HT) memiliki umur panen lebih dalam dibandingkan varietas pembanding Inpari 32 (101 HST) dan Situbagendit (101 HST).
Sementara itu aksesi PH3, PH5, dan PH7 tidak berbeda nyata dengan padi hitam aksesi PH4 dan PH8.

Panjang malai padi hitam berkisar $22.4-23.9 \mathrm{~cm}$ sedangkan varietas pembanding berkisar $20.6-24.1 \mathrm{~cm}$. Karakter panjang malai padi hitam yang diuji tidak berbeda dengan varietas Situbagendit, sedangkan aksesi PH8 tidak berbeda nyata dengan Inpari 32.

Tabel 4. Keragaan Karakter Generatif Padi Hitam di kecamatan Indihiang

\begin{tabular}{lcccllc}
\hline \multicolumn{1}{c}{ Aksesi } & $\begin{array}{c}\text { UB } \\
\text { (HST) }\end{array}$ & $\begin{array}{c}\text { UP } \\
\text { (HST) }\end{array}$ & $\begin{array}{c}\text { PM } \\
\text { (cm) }\end{array}$ & JGI & JGT & $\begin{array}{c}\text { BSB } \\
\text { (g) }\end{array}$ \\
\hline PH3 & $71 \mathrm{~b}$ & $105 \mathrm{a}$ & $23.9 \mathrm{a}$ & $170 \mathrm{ab}$ & $192 \mathrm{~b}$ & 27.6 \\
PH4 & $67 \mathrm{c}$ & $103 \mathrm{ab}$ & $23.3 \mathrm{a}$ & $148 \mathrm{~b}$ & $160 \mathrm{c}$ & 28.8 \\
PH5 & $71 \mathrm{~b}$ & $104 \mathrm{a}$ & $23.1 \mathrm{a}$ & $194 \mathrm{a}$ & $215 \mathrm{a}$ & 26.7 \\
PH8 & $71 \mathrm{~b}$ & $103 \mathrm{ab}$ & $22.4 \mathrm{ab}$ & $176 \mathrm{ab}$ & $199 \mathrm{a}$ & 26.7 \\
PH7 & $74 \mathrm{a}$ & $104 \mathrm{a}$ & $23.2 \mathrm{a}$ & $147 \mathrm{~b}$ & $168 \mathrm{bc}$ & 27.8 \\
Inpari32 & $70 \mathrm{~b}$ & $101 \mathrm{~b}$ & $20.6 \mathrm{~b}$ & $145 \mathrm{~b}$ & $159 \mathrm{c}$ & 30.0 \\
Situbagendit & $67 \mathrm{c}$ & $101 \mathrm{~b}$ & $24.1 \mathrm{a}$ & $151 \mathrm{~b}$ & $163 \mathrm{bc}$ & 28.2 \\
\hline
\end{tabular}

Keterangan : UB (umur berbunga), UP (umur panen), PM (panjang malai), JGI (jumlah gabah isi), JGT (jumlah gabah total (JGT), BSB (bobot seribu butir), huruf yang sama pada kolom yang sama menunjukkan tidak berbeda nyata berdasarkan uji lanjut Duncan 5\%

Karakter jumlah gabah isi padi hitam berada pada kisaran 147 - 194 butir sedangkan varietas pembanding berada pada kisaran 145 - 151 butir per malai. Jumlah gabah isi aksesi padi PH3, PH4, PH7 dan PH8 memiliki jumlah gabah isi tidak berbeda nyata dengan varietas pembanding Inpari 32 dan Situbagendit. Sementara aksesi PH5 memiliki jumlah gabah isi lebih banyak daripada varietas Inpari 32 dan Situbagendit.

Jumlah gabah total berada pada kisaran 160 - 215 butir per malai. Jumlah gabah total aksesi PH4 dan PH7 tidak berbeda nyata dengan varietas pembanding Inpari 32 dan Situbagendit. Sementara PH3 dan PH7 tidak berbeda nyata dengan varietas inpari 32. Aaksesi PH5 (215 butir) dan PH8 (199 butir) memiliki jumlah gabah total lebih banyak dibandingkan varietas pembandingnya.
Bobot seribu butir padi hitam berkisar 27 - 29 g sedangkan padi putih berkisar $28-30 \mathrm{~g}$. Aksesi padi hitam yang diuji tidak menunjukan perbedaan yang nyata terhadap karakter bobot seribu butir.

\section{KESIMPULAN}

Hasil meunjukkan bahwa aksesi yang diuji berpengaruh nyata terhadap karakter tinggi tanaman, panjang daun bendera, umur berbunga, umur panen, panjang malai, jumlah gabah isi, jumlah gabah total, dan tidak berpengaruh nyata terhadap karakter jumlah anakan produktif, jumlah anakan total dan bobot seribu butir. Aksesi PH5 (asal Indihiang) memiliki keragaan terbaik dari aksesi lainnya yaitu memiliki panjang daun bendera $29.9 \mathrm{~cm}$, umur panen 104 hari setelah tanam dan jumlah gabah total 215 butir per malai dibandingkan dengan varietas Inpari 32 dan Situbagendit. 


\section{UCAPAN TERIMA KASIH}

Terima kasih disampaikan kepada Kementerian Riset, Teknologi dan Pendidikan Tinggi yang telah mendanai penelitian ini melalui skim Penelitian Dosen Pemula (PDP) pendanaan tahun 2018.

\section{DAFTAR PUSTAKA}

Anhar, A. (2013). Explorasi dan Mutu 尌 Beras Genotip Padi Merah di Kabupaten Pasaman Barat Sumatera Barat. Jurnal Sains Dan Teknologi, 5(1), 1-5.

Gomez, K. A., \& Gomez, A. A. (1984). Statistical Procedures For Agricultural Research. New York: John Wiley and Sons.

Hartati, S. (2013). Pengaruh Pengolahan 期 terhadap Kandungan Poliphenol dan Antosianin Beras Wulung yang Berpotensi sebagai Makanan Diet Penderita Diabetes Mellitus. Jurnal Pangan Dan Gizi, 4(7), 57-67.

Huang, Y.-P., \& Lai, H.-M. (2016). 尌 Bioactive compounds and antioxidative activity of colored rice bran. Journal of Food and Drug Analysis, 24(3), 564-574. https://doi.org/10.1016/j.jfda.2016.0 1.004

Indrasari, S. D. (2009). Beras untuk 尌 Penderita Diabetes (Warta Pene). Bogor: Badan Penelitian dan Pengembangan Pertanian Departemen Pertanian.

Kristamtini, K., Sutarno, S., Wiranti, E. 琶 W., \& Widyayanti, S. (2016). Kemajuan Genetik dan Heritabilitas Karakter Agronomi Padi Beras Hitam pada Populasi F2. Jurnal Penelitian Pertanian Tanaman Pangan, $\quad 35(2), \quad$ https://doi.org/10.21082/jpptp.v35n2 .2016.p119-124

Kushwaha, U. K. S. (2016). Black Rice EQ Cultivation. In Black Rice (pp. 115150). https://doi.org/10.1007/978-3319-30153-2 8

Maulida, R., \& Guntarti, A. (2015). 顽 Pengaruh Ukuran Partikel Beras Hitam (Oryza sativa L.) Terhadap Rendemen Ekstrak dan Kandungan Total Antosianin. Pharmaciana, 5(1), 9-16.

https://doi.org/10.12928/pharmacian a.v5i1.2281

Moongngarm, A., Daomukda, N., \& E Khumpika, S. (2012). Chemical Compositions, Phytochemicals, and Antioxidant Capacity of Rice Bran, Rice Bran Layer, and Rice Germ. APCBEE Procedia, 2, 73-79. https://doi.org/10.1016/j.apcbee.201 2.06.014

Rohaeni, W. R. (2015). Inventarisasi padi 显 lokal di Kawasan Ciater, Subang, Provinsi Jawa Barat. Pros Sem Nas Masy Biodiv Indon, 1(2), 189-193. https://doi.org/10.13057/psnmbi/m0 10204

Sitaresmi, T., Wening, R. H., Rakhmi, A. E., Yunani, N., \& Susanto, U. (2013). Pemanfaatan Plasma Nutfah Padi Varietas Lokal dalam Perakitan Varietas Unggul. Iptek Tanaman Pangan, 8(1), 22-30.

Suardi, D., \& Ridwan, I. (2009). Beras Elam, Pangan Berkhasiat yang Belum Populer. Warta Penelitian Dan Pengembangan Pertanian, 31(2), 9-10.

Suhery, W. N., Fernando, A., \& Has, N. 顽 (2016). Uji Aktivitas Antioksidan 
Dari Ekstrak Bekatul Padi Ketan Merah Dan Hitam (Oryza sativa L. var. glutinosa) Dan Formulasinya Dalam Sediaan Krim. Pharmacy, 13(01), 101-115.

Surahman, M., Santosa, E., \& Nisya, F. N. 尌 (2009). Karakterisasi dan Analisis Gerombol Plasma Nutfah Jarak Pagar Indonesia dan Beberapa Negara Lain Menggunakan Marka Morfologi dan Molekuler. Jurnal Agronomi Indonesia (Indonesian Journal of Agronomy), 37(3), 256264.

Utami, D. W., Ilhami, A., \& Hanarida, I. 的 (2010). Sidikjari DNA Plasma Nutfah Padi Lokal Menggunakan Marka Molekuler Spesifik untuk Sifat Padi Beras Merah. Berita Biologi, 10(2), 143-150.

Walter, M., Marchesan, E., Massoni, P. F. S., da Silva, L. P., Sartori, G. M. S., \& Ferreira, R. B. (2013). Antioxidant properties of rice grains with light brown, red and black pericarp colors and the effect of processing. Food Research International, 50(2), 698703.

https://doi.org/10.1016/j.foodres.201 1.09 .002

Warman, B., Sobrizal, S., Suliansyah, I., 钢 Swasti, E., \& Syarif, A. (2016). Perbaikan Genetik Kultivar Padi Beras Hitam Lokal Sumatera Barat Melalui Mutasi Induksi. Jurnal Ilmiah Aplikasi Isotop Dan Radiasi, 11(2), 125.

https://doi.org/10.17146/jair.2015.1 1.2.2791 